Жамурзов Ислам Аркадьевич

аспирант Департамента правового регулирования экономической деятельности Финансового университета при Правительстве РФ

\section{УГОЛОВНО-ПРАВОВАЯ ОХРАНА СВОБОДЫ СОВЕСТИ И ВЕРОИСПОВЕДАНИЯ И ПРИНЦИП РАВЕНСТВА ПРАВ И СВОБОД ЧЕЛОВЕКА И ГРАЖДАНИНА}

\section{Аннотация:}

В статье рассматриваются вопросы уголовноправовой охраны свободы совести и вероисповедания в соотношении с принципом равенства прав и свобод человека и гражданина, ставшие остроактуальными в связи с изменениями, внесенными в статью 148 Уголовного кодекса РФ. Сделан акцент на наличии дискриминационной составляющей в этой статье. Так, введение категории верующих противоречит ч. $2 \mathrm{~cm}$. 19 Конституции РФ. Отмечается, что лишь в условиях, когда исповедующие определенную религию не имеют преимуществ над людьми, не исповедующими никакой религии, возможна реализация права на свободу совести $u$ вероисповедания $в$ полном объеме. Утверждается, что сложности, возникающие при применении положений вышеуказанной статьи уголовного закона, вызваны большим количеством оценочных понятий в диспозиции нормы, многие из которых не раскрываются ни в одном нормативно-правовом акте. В заключение представлен ряд рекомендаций по изменению исследуемой статьи уголовного закона для приведения ее в соответствие с конституционными нормами.

Ключевые слова:

свобода совести, свобода вероисповедания, принцип равенства прав и свобод человека и гражданина, светское государство, религия, верующие, атеисты, уголовная ответственность, дискриминация

\section{Zhamurzov Islam Arkadyevich}

PhD student, Department of Legal Regulation of Economic Activity, Financial University under the Government of the Russian Federation

\section{CRIMINAL LEGAL PROTECTION OF FREEDOM OF CONSCIENCE AND RELIGION AND THE PRINCIPLE OF EQUALITY OF HUMAN AND CIVIL RIGHTS AND FREEDOMS}

\section{Summary:}

This study discusses the criminal legal protection of freedom of conscience and religion in relation to the principle of equality of human and civil rights and freedoms that have become urgent because of the amendments to Article 148 of the Criminal Code of the Russian Federation. The emphasis is placed on the discriminatory component of the article. Thus, the introduction of the category of believers into the above-mentioned article contradicts Part 2 of Article 19 of the Constitution of the Russian Federation. The study notes that it is only possible to exercise the right to freedom of conscience and religion in full if believers who practice a religion have no advantage over people who profess no religion. It is argued that the difficulties in applying the provisions of Article 148 of the Criminal Code are caused by many evaluation concepts in the disposition of this rule; most of them are not disclosed in any law or regulation. It is recommended that Article 148 should be amended to bring it into line with constitutional rules.

Keywords: freedom of conscience, freedom of religion, principle of equality of human and civil rights and freedoms, secular state, religion, believers, atheists, criminal liability, discrimination.

Вопросы, связанные с реализацией права на свободу совести и вероисповедания, играют значимую роль в становлении и развитии культурной, политической, правовой и иных сфер жизни современного многонационального и многоконфессионального российского общества. Право на свободу совести и вероисповедания является одним из основных, неотъемлемых прав человека как в рамках международно-правовых отношений, так и внутри государства.

Существуют различные точки зрения по обозначенному вопросу. Так, Ф.М. Рудинский придерживается позиции, согласно которой основной гарантией реализации права на свободу совести и вероисповедания является отделение церкви от государства и школы от церкви. Автор мотивирует это тем, что при освобождении совести от опеки государства у человека возникает возможность для самостоятельного решения вопроса о своих убеждениях [1, с. 651]. По мнению С.А. Бурьянова, наиболее важной гарантией реализации свободы совести является светскость государства [2, с. 9].

Соглашаясь с С.А. Бурьяновым, дополним также, что необходимым условием реализации конституционного права на свободу совести и вероисповедания является равенство прав и свобод человека и гражданина. В светском государстве, каким является Российская Федерация, недопустимо установление официальной государственной религии (ч. 1 ст. 14 Конституции РФ). Таким образом, путем отделения государства от религиозных организаций устанавливаются границы допустимого внешнего регулирования в религиозной сфере, уравниваются права верующих - граждан, исповедующих конкретную религию, и неверующих - не относящих себя ни к одной из конфессий, атеистов. 
Только в государстве, в котором религиозные организации не наделены властью вмешиваться в государственные дела, не оказывают влияния на принятие тех или иных решений, касающихся всего общества в целом, а также граждане которого, относящиеся к определенной конфессии, не имеют преимуществ над людьми, исповедующими иную религию или же не исповедующими никакой религии, возможна реализация конституционного права на свободу совести и вероисповедания. В таких условиях у человека возникает возможность самостоятельного выбора в вопросе исповедования той или иной религии или же отказа от исповедования какой-либо религии вовсе.

Статья 28 Конституции РФ гарантирует свободу совести и вероисповедания, включая «право исповедовать индивидуально или совместно с другими любую религию или не исповедовать никакой, свободно выбирать, иметь и распространять религиозные и иные убеждения и действовать в соответствии с ними» [3]. Для уголовно-правовой охраны данного конституционного права законодателем в Уголовный кодекс РФ была введена статья 148, предусматривающая уголовную ответственность за нарушение права на свободу совести и вероисповедания. Длительное время по данной статье отсутствовала какая-либо судебная практика, пока не произошли события, связанные со скандально известной группой Pussy Riot, которые своими действиями в храме Христа Спасителя оскорбили чувства миллионов верующих. У правоприменителя возникли сложности с квалификацией их преступных действий. Реакцией на случившееся стало внесение законодателем изменений в ст. 148 УК РФ в 2013 г.

Исходя из позиции Конституционного суда, критерием определенности, ясности, недвусмысленности является принцип равенства всех перед законом и судом. Обеспечение такого равенства возможно лишь при условии единообразного понимания и толкования правовых норм всеми правоприменителями. Неопределенность содержания правовой нормы неизбежно ведет к произволу, а значит, и к нарушению принципа равенства и верховенства закона [4].

Однако после изменений 2013 г. под уголовно-правовую охрану стали подпадать только верующие и религиозные организации, тогда как статья именуется «нарушение права на свободу совести и вероисповеданий», следовательно, в равной мере должны защищаться права и свободы как верующих, так и неверующих. Кроме того, законодателем неточно сформулирована уголовно-правовая норма, введены оценочные категории и термины, большинство из которых не определены законодательно ни в одном нормативно-правовом акте. В связи с этим у правоприменителя возникают сложности в использовании данной нормы, чем, в свою очередь, обусловлено малое количество судебной практики.

Например, понятия «верующие», «религиозные чувства» не имеют правового толкования ни в одном законе. При определении этих понятий возникают затруднения даже у религиоведов. По мнению некоторых ученых, под религиозными чувствами необходимо понимать чувства, эмоции людей, вызванные религиозными переживаниями. А.Ю. Григоренко отмечает, что такие чувства, как любовь, страх, надежда и т. д., приобретают религиозный характер лишь при соединении их с верой в сверхъестественное [5].

На наш взгляд, необходимо исключить понятие «религиозные чувства» из диспозиции ст. 148 УК РФ, так как эта категория не является правовой и не имеет четкого определения, что недопустимо в тексте уголовного законодательства.

Для раскрытия понятия публичности необходимо обращаться к статьям, предусматривающим наказания за совершение преступлений экстремистской направленности (ст. 205.2, 280 и 280.1 УК РФ), где оно объясняется в контексте публичного призыва к экстремистской деятельности.

Одним первых уголовных дел по ст. 148 УК РФ, которое наглядно демонстрирует сложности, возникающие в процессе применения статьи, является дело Виктора Краснова, получившее широкий резонанс в средствах массовой информации. Так, гражданин Краснов в процессе спора в социальной сети «ВКонтакте» под псевдонимном «Колосов Виктор» оставил комментарий, оскорбивший чувства верующих («Бога нет», «Библия - сборник еврейских сказок», «овцы Христовы»). Производство по уголовному делу было прекращено в связи с истечением срока давности уголовного преследования в феврале 2017 г.

Преступление, предусмотренное ст. 148 УК РФ, относится к категории небольшой тяжести, а срок давности привлечения к уголовной ответственности по ней составляет два года, однако процесс по делу Краснова затянулся на более продолжительный срок. Это позволяет сделать вывод, что у правоприменителя возникли сложности в ходе предварительного следствия. Вероятнее всего, это связано не только с большим количеством оценочных категорий, но и с тем, что отсутствуют какие-либо методические рекомендации по расследованию данных категорий дел, разъяснения Пленума Верховного суда РФ, эффективная правоприменительная практика. Так, вероятно, сложности возникали при формулировке вопросов, которые необходимо было поставить перед экспертом при назначении судебно-лингвистической экспертизы. Эксперты в свою очередь в связи с отсутствием рекомендаций и практики не могли провести ее надлежащим образом. Кроме того, 
в процессе предварительного следствия не был раскрыт такой признак, как «явное неуважение к обществу»; не было уточнено, какие конкретно религиозные чувства оскорблены и в какой фрорме это произошло; не установлено, каким образом «верующий» признается таковым; не выявлено, каким именно образом причинен моральный вред; не доказано наличие прямого умысла.

Часть 1 ст. 29 Конституции РФ гарантирует каждому право на свободу мысли и слова. В ч. 4 статьи установлено право свободно искать, получать, передавать, производить и распространять информацию любым законным способом. Однако статья 148 УК РФ ограничивает данную норму. Это связано с тем, что возникают сложности определения правомерного и неправомерного поведения в процессе дискуссии на темы религиозного характера. Например, отрицание бога в процессе дискуссии правоприменителем может быть расценено и как преступное, и как непреступное. Так, по делу Виктора Краснова была проведена комплексная судебная психолого-лингвистическая экспертиза в отношении комментариев, оставленных им во «ВКонтакте». Помимо многочисленных нарушений уголовно-процессуального закона, оскорбляющим чувства верующих было признано отрицание существование бога, что идет в разрез с ч. 4 ст. 29 Конституции РФ.

Исходя из вышеизложенного, можно заключить, что существует настоятельная необходимость внесения изменений в ст. 148 УК РФ, так как в действующей редакции норма полностью антиконституционна, нарушает основополагающий принцип равенства всех перед законом вне зависимости от отношения к религии.

На наш взгляд, следует исключить из диспозиции ст. 148 УК РФ понятие «религиозные чувства», так как эта категория не является правовой, в связи с чем не представляется возможным ее законодательное истолкование. Любая попытка дать законодательное определение приведет лишь к нарушению юридической техники.

Необходимо исключить категорию верующих или ввести категорию неверующих и ответственность за воспрепятствование законной деятельности атеистических организаций в целях недопущения нарушения принципа равенства прав человека и гражданина, а также конституционного права на свободу совести и вероисповедания.

Диспозиция ч. 1 ст. 148 УК РФ должна выглядеть следующим образом: «Публичные действия, выражающие явное неуважение к обществу и совершенные в целях оскорбления чувств человека в связи с его убеждениями и (или) отношением к религии».

Следует также разработать понятийный аппарат путем законодательного толкования оценочных категорий, таких как «публичность», «оскорбление», «явное неуважение к обществу», в примечании к ст. 148 УК РФ или в соответствующем постановлении Пленума ВС РФ.

\section{Ссылки:}

1. Рудинский Ф.М. Наука прав человека и проблемы конституционного права: труды разных лет. М., 2006. 1234 с.

2. Бурьянов С.А. Светскость государства и международно признанная свобода совести. Теоретико-прикладное исследование за 2015-й - начало 2016 г. М., 2016. 258 с.

3. Конституция Российской Федерации : принята всенар. голосованием 12 дек. 1993 г. : с учетом поправок, внес. законами РФ от 30 дек. 2008 г. № 6-ФКЗ, от 30 дек. 2008 г. № 7-ФКЗ, от 5 февр. 2014 г. № 2-ФКЗ, от 21 июля 2014 г. № 11-ФКЗ // Собрание законодательства РФ. 2014. № 31. Ст. 4398.

4. По делу о проверке конституционности отдельных положений Закона РСФСР «О государственной налоговой службе РСФСР» и законов Российской Федерации «Об основах налоговой системы в Российской Федерации» и «О федеральных органах налоговой полиции» : постановление Конституционного суда РФ от 15 июля 1999 г. № 11-П // Вестник Конституционного суда РФ. 1999. № 5. С. 48-56.

5. Религиоведение : учебное пособие для студентов педагогических вузов / под ред. А.Ю. Григоренко. СПб., 2008. 507 с.

\section{References:}

Buryanov, SA 2016, Secularism of the State and Internationally Recognized Freedom of Conscience. Theoretical and Applied Research for 2015 - Early 2016, Moscow, 258 p., (in Russian).

Grigorenko, AYu (ed.) 2008, Religious Studies: a Textbook, Saint Petersburg, 507 p., (in Russian).

Rudinsky, FM 2006, The Science of Human Rights and the Problem of Constitutional Law: Works of Different Years, Moscow, 1234 p., (in Russian). 